\title{
Discussion on the Influence of Mobile Phone on Ideological and Political Education in Universities
}

\author{
Jing Chen \\ Henan University \\ Kaifeng, Henan, 475000
}

\begin{abstract}
With the cellular "3G" and "4G" era arrival, the extensive use of mobile media has an enormous influence on college students, which has brought both new opportunities and challenges to the ideological and political education in universities. And all universities shall pay high attention and carefully analyze the effect so as to draw on advantages and avoid disadvantages.
\end{abstract}

Keywords-higher education; mobile media; ideological and political education

Since the cellular " $3 G$ " especially " $4 G$ " technology was officially put into operation, the development of mobile media has been unstoppable and has penetrated into every aspect of people's life. University is the forefront of China's information and network coverage areas and college students are a youthful and dynamic group who have advanced perception of trend, are able to quickly accept novel achievements brought by all kinds of new technologies and play an important role of experiencer and communicator in their application and promotion. By far, the mobile media application has become an indispensable part of contemporary college students' study and life, having been changing the students' living and learning style as well as their way of thinking and view of value. Therefore, ideological and political educators in universities shall recognize the influence of mobile media use on college students' ideological and political education, actively analyze this effect and then strengthen and improve the ideological and political education for college students.

\section{OPPORTUNITIES BROUGHT BY MOBILE MEDIA TO IDEOLOGICAL AND POLITICAL EDUCATION IN UNIVERSITIES}

\section{A. The mobile media setting up a broader platform for the ideological and political work in universities}

Before the arising of network media, the ideological and political education in universities is confined to traditional teaching method, which has restricted the amount of information conveyed to college students and achieved limited effects. The rising of network media provides inexhaustible resource for the ideological and political education which has made great progress since then. The extensive use of mobile media has realized the rapid transmitting of the information characterized by large amount, abundant resources and wide coverage, breaching the limits of time and space and ensuring that the users can receive not only the text but also the sound, image, picture and other sorts of information, which, compared with the communication technologies and tools of any past eras, have accomplished the qualitative leaps.

In view of this, on the one hand, ideological and political educators can improve the human-created civilization achievements by using the large amount of resources provided by $3 \mathrm{G}$ technology and then pass it to students. On the other hand, they can use the mobile media to spread the themes relating to the promotion of the main melody of socialism, socialist core values, etc. to college students, making education keep pace with the times. Meanwhile, educators may present the knowledge to students by mobile phone short message, QQ, blog, micro-blog, etc. The changing of traditional education mode and method is able to effectively prevent the occurrence of students' antagonism and make the ideological and political education in universities more enlightened and true-to-life. The mobile media undoubtedly has set up a whole-new broad platform for the ideological and political education in universities.

\section{B. The mobile media breaching the limits of time and space in ideological and political education}

Traditionally, the ideological and political education in universities is performed mainly by classroom teaching mode and with supplementary methods of heart-to-heart talk, social practice and discussion which are limited by time, space, resource and other factors, which makes the resources not only unable to be fully grasped but also unable to be used by demanders at any time. However, with mobile media, educators can communicate with students and conduct the ideological and political education through mobile phones any place any time; at the same time, emerging problems in the traditional ideological and political education work, such as the confined approach of information exchange, lack of resources for information exchange, etc., have been alleviated. By the use of mobile media, "the ideological and political work in universities can break through the time and space limitations, transcending from flat-dimension to three-dimension, changing from static to dynamic, thereby enhancing the interactivity and interestingness as well as improving the attraction and appeal of ideological and political education for college students". Every time when college students need help, they can timely inquire of teachers or classmates via mobile media, which fully indicates the realization of interactivity and especially pertinence, breaching the limits of time and space. This real-time interaction will change the mode of ideological and political education from one-way indoctrination to two-way interaction, allow educators, whenever and wherever possible, 
to know and grasp the college students' basic trend and ideological state through mobile phone and then carry out ideological and political education specifically, thereby forming the "four-in-one" ideological and political education system involving school, society, family and individual.

\section{The mobile media bringing new ways and means for the ideological and political education in universities}

The method of "indoctrination" has been commonly adopted for the traditional ideological and political education in universities. Most students receive the education passively via either classroom indoctrination or separate conversation, which makes students feel boring and easily be resistant. And with the increasing development of modern tools for social information dissemination, the traditional education means have even less affinity and appeal to a new generation of college students, which greatly impairs the effect of ideological and political education. The rising of mobile media has provided educators the conditions for innovation of education ways and means.

Since the mobile media and internet are mutually integrated, via mobile media, educators may set up a network platform and establish QQ group, Fetion, blog, micro-blog, We-Chat and so on to send the contents about ideological and political education to all the students. In this way, educators can deliver the humanized and personalized information easier and faster, within the shortest time, timely transmitting the selected education content to students and rapidly getting the respond accordingly, so as to make the education more direct, thorough and effective. Meanwhile, daily life management can be provided for students to substantially improve the work efficiency.

\section{The virtuality of network bringing the ideological and political work closer to students}

Network blurs the boundary between real world and virtual world, but $3 \mathrm{G}$ technology fundamentally breaks the barriers of people in cyber world, having built an invisible bridge between individuals and having changed people's traditional communication mode. In this virtual cyber world, the people's gender, age, appearance and occupation have been covered up, and without the inequality in reality, people exist just as "symbols". This virtual environment and role in interpersonal communication make both sides more equal and secretive, which imperceptibly narrows the interpersonal psychological distance, reduces the psychological prevention to some extent and relieves the contact stress in real life.

The virtuality of network provides the possibility of equal communication and silent transforming influence for college students' ideological and political education. In the ideological and political education, educators can take full advantage of this network virtuality, making the relationship between teacher and student equal and dynamic. The two sides may communicate with each other equally: students can pour out the inmost confusion and aguish as well as the inspirations in life, and then teachers can give guidance and instruction specifically for some questions that students have encountered in life, study and thoughts, which will achieve unexpected results. Meanwhile, in this way, the face-to-face awkward can be avoided and the results of teaching by this way will be far better that that by simply preaching.

\section{Challenges BROUGHT BY MOBILE MEDIA TO} IDEOLOGICAL AND POLITICAL EDUCATION IN UNIVERSITIES

The extensive use of mobile media has brought so many opportunities to the ideological and political education for college students. However, at the same time, we shall realize that the mobile media is a double-edged sword to the college students' ideological and political education, which will also bring new challenges. The mobile media can provide better services for the ideological and political education only after the challenges have been learned and accepted.

\section{A. Challenges posed for ideological and political educators}

The educators' understanding and application of $3 \mathrm{G}$ network will directly affect the work implementation and effects. However, with large gap between age levels, the universities' teachers are in a inferior position for information, lagging far behind the college students in acceptance and application of new things. Therefore, educators shall take the initiative to learn and apply $3 \mathrm{G}$ network since the improvement of the ability to use the new media is an inevitable requirement to meet the challenges. Meanwhile, the openness of network and magnanimity of information also have an impact on the teachers' dominant status and authority. In era of $3 \mathrm{G}$ network, students may quickly find out all sorts of public or internal, true or false information by their carry-on mobile phones and it's easy for them to cast doubt on what teachers have taught. If teachers lack the sensitivity to accept new things and have no sufficient persuasion for what they have taught, their authority then will be affected.

\section{B. Challenges posed for the university students' identification ability}

As an open media tool, mobile media pushes over the "ivory tower" in the traditional college life, to make students concern about every phenomenon of the society, to broaden their horizons and also add a lot of fun for their campus life. However, it can not be ignored that China's $3 \mathrm{G}$ network technology has just started and the relative control is not completed, while the personal thought and speech for contention, the baleful information intermingled among the helpful ones are full of networks, with hedonism, extravagance and carnalism bruited on the networks and even some anti-socialist and anti-Marxist rhetoric spread on mobile media. College students have strong curiosity, strong sensitivity and plasticity, and their world view, life view and value view have not formed finally, in lack of information discriminability and discretion and bad information resistance, so they often lose their ability to discriminate between the true and the false when they receiving the information from the mobile media. "The free dissemination of these information often makes college students break away from moral constraints of the society, to indulge themselves in bad behavior and forget their social responsibilities, while those mussy information unscreened often make students lose their ideals and beliefs and make them diverge form right life ideal, beliefs and value view." These bad information also impact the right value view of a few of college students, to make the students in lack of integrity and social responsibility, make them weak-willed and 
depressible-fighting willed, in pursuit of hedonism and carnalism and other bad habits, and even some college students are infected by the western ideology, to think only the political system of western capitalist is excellent and to oppugn the road to socialism. This situation has seriously hindered the healthy growth of college students, increasing the difficulty of the ideological and political education work.

\section{Adverse for the improvement of college students' abilities in all aspects}

The students at the colleges should improve their abilities to learn, to behave, to make interpersonal skills, to work and to survive, all of which must be cultivated by listening and thinking carefully in the classes, butting into other thoughts, referring to documents in libraries, making exchanges and cooperation with others in extra-curricular activities and doing exercise in the social practice. However, in the era of $3 \mathrm{G}$, the large Internet information, with its timely and easy dissemination creates the convenient access to information for college students, but also it is gradually replacing the ability of students to make independent thinking, and most students may produce dependence on it, so that they usually do not want to think about, and when they have a problem, they will use their mobile phone to searching for answers in the "Baidu" "Google" but not solve it by their independent thinking. In the case, many students do not listen carefully in class and not study intensively after school, and when they have a problem, they won't think it actively or consult teachers or discuss with students but they use the phone to search answers in the "Baidu". Moreover, the mobile phone has become a cheating tool of a few of students, by which the students go online to search and pass the answers in exam. This greatly weakens the ability of students to innovate, not helpful for cultivating the learning ability of students. And some students have no self-discipline, and they do not use mobile media for learning, but all day indulge in mobile networks for violence, pornography and game, hardly extricating themselves. They often stay up to 2:00 and even 3:00 in the wee hours, seriously affecting their rest and eventually resulting in their will comedown and study neglect.

Meanwhile, the virtual exchanges of mobile media can easily lead to the interpersonal difficulties of college students. Most students use mobile Internet for "dating chat", which decreases the real life and intercourse time of students, for some students prefer to stay in the dormitory for chatting on line in their spare time, rather than go out for community activities. If college students are wild about virtual exchanges and contact with the outside world only by social networks for long term, Their interpersonal range will be narrowed and their ability to communicate with others gradually reduced, and they will become withdrawn, no self-confident, doubtful of others and reluctant to contact with the outside world, and even get mental disorders and lose the opportunity to make self-understand and self-reflect, so as to have a bad impact on their physical and mental health, and when they step into the society, they can't get out the virtual world quickly and even lose their basic ability to survive.

Anyway, as committed to the ideological and political education, educators shall be aware of the inevitable trend of mobile media application, attach great importance to the influence of mobile media on college students, continuously use the mobile media to strengthen the regulation and application of the ideological and political education for college students, inhibit its negative effect and develop its positive function, thereby bringing about a new situation for the college students' ideological and political education.

\section{REFERENCES}

[1] China Internet Network Information Center (CNNIC), The 29th Statistical Report of China's Internet Network Development

[2] Feng Gang, Study on Functions of New Media Technology in Ideological and Political Education, Beijing Education, 2011 (6).

[3] Ji Haiju, The Dynamic Generation of "Carrier Resultant Force" of College Ideological and Political Education: In the Perspective of New Media Context, Social Sciences in Nanjing, 2010 (12). 